International Journal of Language Education

Volume 5, Number 3, 2021, pp. 135-151

ISSN: $2548-8457$ (Print) 2548-8465 (Online)

Doi: https://doi.org/10.26858/ijole.v5i3.19506

\title{
Writing in a Foreign Language: The Rhetorical and Argument Styles in Research Article Drafts by Nonnative Speakers of English in Linguistics and Language Education
}

\author{
Safnil Arsyad \\ Bengkulu University, Indonesia \\ Email:safnil@unib.ac.id \\ Sahril Nur \\ Makssar State University, Indonesia \\ Email: sahrilfbsunm@unm.ac.id \\ Ahmat Nasihin \\ Bengkulu University, Indonesia \\ Email:ahmad_nasihin21@yahoo.com \\ Syahrial \\ Bengkulu University, Indonesia \\ Email:eric.syahrial@gmail.com \\ Zifirdaus Adnan \\ University of New England, Australia \\ Email: zadnan@une.edu.au
}

Received: 04 March 2021

Reviewed: 1 July 2021-31 September 2021

Accepted: 1 October 2021

\begin{abstract}
Unlike for lecturers in Engineering, Medicine, Computer Science, and Agriculture and Biology Sciences, for Indonesian lecturers in Social Sciences and Humanities including in Linguistics and Language Education (henceforth LLE), publishing research articles in reputable or indexed international journals is very difficult. The possible cause of the difficulty is their unfamiliarity with the correct and appropriate use of rhetorical style in their articles as expected by international journal readers. This study is aimed at investigating the rhetorical of research article (RA) drafts written in English by Indonesian lecturers in Applied Linguistic and English Language Education in five different universities in Indonesia (i.e., Bengkulu University, Padang State University, Atmajaya Catholic University, Mataram University, and Makassar State University). A corpus of 20 English RA drafts was analyzed on their rhetorical and linguistic quality using a genre-based method. The results show that the majority of the RA drafts have addressed important moves in each section of the articles but in terms of the argument quality still needs improvement. This implies that the Indonesian university lecturers in LLE need to be familiar with and able to argue well in their article drafts as it is expected by international readers.
\end{abstract}


Keywords: article drafts; rhetorical and argument style; linguistics and language education; genre-based method

\section{Introduction}

University lecturers in Indonesia have better access to research funds nowadays since the government requires universities in Indonesia to allocate sufficient funds for their lecturers to do research as far as the results are published in national accredited or international reputable journals. However, to many lecturers especially those in Social Sciences and Humanities including in Linguistics and Language Education or LLE publishing an article in international reputable or indexed journals is a daunting task (Adnan, 2014; Arono \& Arsyad, 2019 and Arsyad \& Adila, 2018). This is why very few Indonesian lecturers in Social Sciences and Humanities are successful in publishing their research articles in a reputable international journal (Kementerian Riset, Teknologi, dan Pendidikan Tinggi, 2016). Data from Kemristekdikti show that, unlike lecturers from Engineering, Medicine, Computer Science and Agriculture, and Biology Science, lecturers in Social Sciences and Humanities contribute only $5.65 \%$ of the total publication of Indonesian scholars in an international journal in 2016.

One possible reason for the low level of publication in international journals of lecturers in Social Sciences and Humanities is that their mastery of English is still weak so that it is difficult for them to use references in international English-language journals that are widely available online and to write articles in English properly and appropriately for international publication. Another possible cause is that Indonesian academics may not understand the standard rhetoric style of each section and subsection of research articles (RAs) in English as suggested by (Swales, 1990 and 2004). It has been found that there are differences and similarities in the rhetorical and linguistic style of scientific articles in Indonesian and English (Arsyad, 2001; Mirahayuni, 2002; Adnan, 2009; Arsyad \& Wardhana, 2014; Arsyad \& Arono, 2015 and Arsyad \& Arono, 2016).

From the discourse and linguistic point of view, a good research article must be written rhetorically and grammatically correct and appropriate; that is an article that meets all requirements of a good article as commonly found in the articles published in reputable international journals. Swales (1990 \& 2004) suggest, for example, an article abstract should be written in five rhetorical moves, an article introduction should be written in three rhetorical moves and an article discussion section should be written at least in three rhetorical moves. Concerning the linguistic features of an article, Swales suggests that the method section should be written mostly in the past tense, in citing other's work in their articles authors can use three possible tenses (i.e., present tense, past tense, and present perfect tense) while in the discussion section authors should use hedges to show the uncertainty of the cause or interpretation of their research findings.

\section{Literature review}

Studies on the rhetorical style as well as linguistic features of research articles (RAs) written in Indonesian by Indonesian authors and published in Indonesian journals can be found in the literature. Among these studies are those by Arsyad (2001), Adnan (2009), Arsyad (2013.a), Arsyad (2013.b), Arsyad \& Wardhana (2014) and Arsyad \& Arono (2016). The main purpose of these studies is to find out what the similarity and differences of the rhetorical style and linguistic features are between the Indonesian RAs by Indonesian writers in different fields of discipline and those written in English and published in international journals. The majority of these studies found that the rhetorical style and linguistic features of Indonesian RAs by Indonesian authors are different from those of English RAs by international authors. 
From his study results, Arsyad (2001) proposed a rhetorical pattern model called problem justifies project (PJP) that is more suitable to accommodate the communicative unit contained in the introduction section of the Indonesian RAs in the field of social sciences and humanities. This model is different from that suggested by Swales (1990 \& 2004) called CARS (creating a research space). Unlike in CARS model, the PJP model has four Moves and each Move has more Steps compared to what is in Swales' CARS model. According to Arsyad (2003), the PJP model can better accommodate various communicative units found in the introduction section of Indonesian RAs in social sciences and humanity than the CARS model does. Arsyad further explained that the additional Move in the PJP model is specifically found in Move 1 (establishing shared background knowledge with readers) which is not found in the CARS model. This Move 1 is used to anticipate journal readers who come from different fields. This is because, unlike in English RAs, the purpose of the introduction section in Indonesian RAs is to present the rationale for doing the research, to guide readers in reading the entire article, and to announce the contribution of the research results to the existing knowledge (Rifai, 1995).

Adnan (2009) analyzed the rhetorical structure of RA introductions written by Indonesian authors in the field of education using the CARS model from Swales as a guideline. He discovered that of the twenty-one introduction sections in his research corpus, none of them is similar to the rhetorical style of the introduction section in English RAs as suggested by Swales (1990). The main difference, according to Adnan, is that in Move 1 (establishing a territory) the majority of Indonesian writers discuss the importance of their research topics by referring to practical problems experienced by ordinary people or government rather than by referring to scientific discourse community. Besides that, none of the Indonesian authors supported the importance of their research by referring to the gap or niche in previous relevant research results or findings as in Move 2 in Swales' CARS model (Swales, 1990: 141). Adnan proposes an ideal model of problem solution called ideal problem solution (IPS) which is a modification to the Swales' CARS model to capture the different communicative units in the introduction section of Indonesian RAs especially in the discipline of education.

Research by Arsyad \& Wardhana (2014) and Arsyad \& Arono (2015) focused more on the analysis of the rhetorical patterns and linguistic features of introduction sections of Indonesian RAs in the field of social sciences and humanities. Their results support the findings of previous studies that there is a difference between the rhetorical style of the introduction section of Indonesian RAs and English RAs. According to Arsyad \& Arono (2016), the differences are as follows. First, for Indonesian authors preparing readers' knowledge to read the articles is considered important. Second, Indonesian authors tend to support the importance of their research topic or title with personal and practical reasons rather than concerning previous research. Third, Indonesian authors tend to support the importance of their research activities in a subjective and personal way.

The rhetorical style of other parts of RAs written in Indonesian (i.e., abstract, methodology, and results and discussion) has also been investigated by Arsyad (2013b.) and Arsyad (2014). Arsyad (2013b.) examined the discussion section of 47 RAs in Indonesian written by Indonesian authors in the field of social sciences and humanities published in Indonesian journals. By using the eight Move model (background of information, statement of results, (un) expected outcome, reference to previous research, explanation, exemplification, deduction and hypothesis and recommendation) from Swales (1990), Arsyad found that the eight Move model is quite effective in evaluating the communicative units found in the discussion section of Indonesian RAs although with some differences. The difference is, unlike in English RAs, Move 4 (a reference to previous 
research findings) is rarely used. According to Arsyad, this difference is partly due to the different guidelines for writing RAs in Indonesian and in English.

Research on the rhetorical style of the Indonesian method section was carried out by Arsyad (2013b.). Arsyad investigated the rhetorical style of 51 RA methods sections in the field of social sciences and humanities using the seven Move model (overview, location, research aim/question/hypotheses, subjects/materials, procedures, limitations, and data analysis) from Peacock (2011:102). Arsyad's research results show that 1) the Seven Move model from Peacock is effective enough to capture various communicative units contained in the methods section of Indonesian RAs in social sciences and humanities, 2) in terms of the appearance of Moves and Steps, Indonesia RAs are similar to those of English, and 3) the use of discourse markers is more often found in Indonesian RAs than those in English. From the results of this study, Arsyad concluded that Indonesian writers would not encounter significant difficulties in terms of rhetorical style when writing the research method section of RAs in English since they are similar.

The rationale for the study

As presented above, the majority of the studies on the rhetorical style and linguistic features of RAs in Indonesian or English by Indonesia authors were conducted on the finished products or articles already published in national or international journals. These articles have been revised and edited by the writers following the suggestions, comments and corrections from the journal reviewers and editors. Therefore, the results of these studies cannot reveal the rhetorical and linguistic errors or weaknesses often made by Indonesian authors when writing RAs in English. This is because the already published articles had gone through reviewing and editing processes assisted by the journal editors and/or reviewers until the articles were accepted for publication. This is the rationale for this study; that is to investigate the rhetorical and linguistic errors and weaknesses often made by Indonesian lecturers in Applied Linguistics and English Language Education in writing RA drafts in English. This study was particularly conducted to answer the following questions.

1) How do Indonesian scholars in LLE rhetorically organize their abstracts, introductions, method, results and discussion sections in their English RA drafts? and

2) How do Indonesian authors craft an argument for the importance of their research and/or finding in their RA abstract, introduction and discussion?

\section{Method}

To answer the research questions and thus achieve the objectives, this study employed a mixed-method, simple quantitative and with emphasis on qualitative following Creswell (2009). Twenty lecturers from 5 different universities in Indonesia: Bengkulu University (Unib), Padang State University (UNP), Atmajaya Catholic University (ACU), Mataram University (Unram) and Makassar State University (UNM) in Applied Linguistics and Language Education participated in this study. The distribution of the respondents from five different universities in Indonesia is summarized in the following table.

Table 1. Distribution of RA Drafts in the Corpus of this Study

\begin{tabular}{llccc}
\hline No & \multicolumn{1}{c}{ University } & Code & $\begin{array}{c}\text { Number of } \\
\text { Drafts }\end{array}$ & $\begin{array}{c}\text { Average Number of } \\
\text { Words/Article }\end{array}$ \\
\hline 1. & University of Bengkulu & Unib & 6 & 5,995 \\
\hline 2. & Padang State University & UNP & 4 & 5,978 \\
\hline 3. & Mataram University & Unram & 2 & 5,894 \\
\hline
\end{tabular}




\begin{tabular}{llccc}
\hline 4. & Makassar State University & UNM & 4 & 6,071 \\
\hline 5. & Atmajaya Catholic University & ACU & 4 & 6,159 \\
\hline Total & & & 20 & 6,019 \\
\hline
\end{tabular}

The majority of the participants in this study already had a doctoral degree in Linguistics and Language Education (LLE) obtained either in an English-speaking country or from a university in Indonesia. They were asked to submit a research article (RAs) draft written in English; then their RA drafts were analyzed using rhetorical models of RA sections (ie., abstract, introduction, methods and results, and discussion) following the models suggested by Peacock (2011) of RA abstracts, Swales (1990 \& 2004) of RA introduction, Lim (2006) of RA method, and Swales and Feak (2009) of RA results and discussions. The adapted models are presented below.

Table 2. Rhetorical Model for Research Article Sections

\begin{tabular}{|c|c|c|}
\hline RA Sections & Structural Moves & Description of their functions of the Moves \\
\hline \multirow[t]{5}{*}{ Abstract } & Move 1: Introduction & $\begin{array}{l}\text { Statements about the research topic or what do we } \\
\text { know about the topic or why is the topic important }\end{array}$ \\
\hline & $\begin{array}{c}\text { Move 2: Objectives/ } \\
\text { purposes }\end{array}$ & $\begin{array}{l}\text { Statements about the objective of the research or what } \\
\text { is this study about }\end{array}$ \\
\hline & Move 3: Methods & $\begin{array}{l}\text { Statement about how a study has been conducted or } \\
\text { How was it done. }\end{array}$ \\
\hline & Move 4: Results & $\begin{array}{l}\text { Statement about what has been found in the research } \\
\text { or what was discovered }\end{array}$ \\
\hline & Move 5: Conclusion & $\begin{array}{l}\text { Statement about the conclusion, implication or } \\
\text { recommendation of the research findings or what do } \\
\text { the findings mean. }\end{array}$ \\
\hline \multirow[t]{3}{*}{ Introduction } & $\begin{array}{c}\text { Move 1: Establishing a } \\
\text { territory }\end{array}$ & $\begin{array}{l}\text { Statement about showing that the general research } \\
\text { area is important, central, interesting, problematic, or } \\
\text { relevant in some way or introducing and/or reviewing } \\
\text { items of previous research in the area }\end{array}$ \\
\hline & $\begin{array}{l}\text { Move 2: Establishing a } \\
\text { niche }\end{array}$ & $\begin{array}{l}\text { A statement indicating a gap in the previous research } \\
\text { and/or extending previous knowledge in some way }\end{array}$ \\
\hline & $\begin{array}{l}\text { Move 3: Occupying the } \\
\text { niche }\end{array}$ & $\begin{array}{l}\text { Statement about presenting the present work by } \\
\text { outlining the purpose, listing the research questions, } \\
\text { announcing the principal findings, stating the value of } \\
\text { the present research, and indicating the structure of the } \\
\text { research article }\end{array}$ \\
\hline \multirow[t]{3}{*}{ Methods } & $\begin{array}{l}\text { Move 1: Describing data } \\
\text { collection } \\
\text { procedure/s }\end{array}$ & $\begin{array}{l}\text { Description of data collection techniques including 1) } \\
\text { description of the location of the sample, the size of } \\
\text { the sample/population, characteristic of the sample, } \\
\text { sampling technique or criterion, 2) recounting steps in } \\
\text { data collection, and 3) justifying the data collection } \\
\text { procedures }\end{array}$ \\
\hline & $\begin{array}{l}\text { Move 2: Describing } \\
\text { procedures for } \\
\text { measuring } \\
\text { variables }\end{array}$ & $\begin{array}{l}\text { Description of research procedures including 1) } \\
\text { presenting an overview of the design, 2) explaining the } \\
\text { method of variables, and 3) justifying the methods of } \\
\text { measuring variables }\end{array}$ \\
\hline & $\begin{array}{l}\text { Move 3: Describing data } \\
\text { analysis } \\
\text { procedure/s }\end{array}$ & $\begin{array}{l}\text { Description of the process of data analyses including } \\
\text { 1) statistical calculation for quantitative research, 2) }\end{array}$ \\
\hline
\end{tabular}




\begin{tabular}{|c|c|c|}
\hline & & $\begin{array}{l}\text { justifying data analyses procedures, and 3) previewing } \\
\text { results }\end{array}$ \\
\hline \multirow[t]{6}{*}{$\begin{array}{l}\text { Results \& } \\
\text { Discussion }\end{array}$} & $\begin{array}{l}\text { Move 1: Background } \\
\text { information about } \\
\text { the research }\end{array}$ & $\begin{array}{l}\text { Statement about 'theoretical and technical information } \\
\text { as already addressed earlier in the RA }\end{array}$ \\
\hline & $\begin{array}{l}\text { Move 2: Statement of } \\
\text { results }\end{array}$ & $\begin{array}{l}\text { A claim made by the writer as the direct answer to their } \\
\text { research question }\end{array}$ \\
\hline & $\begin{array}{l}\text { Move 3: Statement of } \\
\text { (un)expected } \\
\text { findings }\end{array}$ & $\begin{array}{l}\text { Statement or comment on whether or not the research } \\
\text { results or finding as they are expected }\end{array}$ \\
\hline & $\begin{array}{l}\text { Move 4: Reference to } \\
\text { previous relevant } \\
\text { studies }\end{array}$ & $\begin{array}{l}\text { a rhetorical attempt of writer/s to link the present } \\
\text { research finding/s to the available relevant knowledge } \\
\text { or information for the purpose } \\
\text { of comparison or to support the present findings }\end{array}$ \\
\hline & $\begin{array}{l}\text { Move 5: Explanation of } \\
\text { research results }\end{array}$ & $\begin{array}{l}\text { Author's rhetorical attempt to logically convince } \\
\text { readers why such unexpected or extraordinary results } \\
\text { or findings of the present study occur }\end{array}$ \\
\hline & $\begin{array}{l}\text { Move 6: } \begin{array}{l}\text { Illustration to } \\
\text { support the } \\
\text { research results }\end{array}\end{array}$ & $\begin{array}{l}\text { Illustration or samples to strengthen or support the } \\
\text { Explanation of research findings }\end{array}$ \\
\hline
\end{tabular}

As shown above, every section of an RA has a standard rhetorical model as suggested by the findings of previous studies on RAs written in English and published in international journals. It is important to note here that in Swale's model of results and discussion section, there are 8 moves but in this study there are only 6 Moves; Move 7 (Deduction and hypothesis or Interpretation of research findings) and Move 8 (Suggestions or recommendation) are considered to be the conclusion and recommendation section of an article. These models were used as a guideline in analyzing 20 RA drafts written by Indonesian academics in Linguistics and Language Education in Indonesia.

In this study, following Safnil (2001, p. 82), a communicative unit or Move is defined as 'a clause or a set of clauses or a paragraph which shows a clear indication of a specific identifiable communicative purpose, signalled by linguistic clues or inferred from specific information in the text'. The processes of identifying the Moves in all sections of the RA drafts, following DudleyEvans (1994), went through the following steps. First, the titles, the abstracts, and the key terms in each of the articles were read to get a general understanding of the research activities reported in the RAs. Second, the entire article was read to identify the main sections (i.e. abstract, introduction, methods, results and discussion, and conclusion). Third, every section of the RA drafts was read again to identify the linguistic and discourse clues which may signal the possible communicative units in each section referring to the above models as a guideline. Fourth, the possible moves and steps were identified and coded with the help of linguistic and discourse clues such as subheadings, paragraphs as a unit of ideas, specific lexicons, discourse markers, and/or inferred from the text. Finally, an independent rater was asked to identify the moves and steps found in all sections of the RA drafts to ensure the inter-rater reliability of text analysis results.

To answer the second, third, and fourth research questions, we looked at further on how the authors argue for the importance of their research in their RA abstract, introduction, and discussion. This is because, as Baber (2018) claims, 'Arguments in the genre of academic writing in the humanities are explicated through their structure and by their location in the academic article' (p.30). In the abstract, for example, we further analyzed Move 1 because in this move 
authors usually address why the study is important and/or interesting (Peacock, 2011). In the introduction section, attention was given to Move 2 because this is where the authors argue for the importance of their research (Swales, 1990 \& 2004). In the discussion section, we further analyzed Move 4 (a reference to previous relevant studies) and Move 5 (explanation of research results) because in these two moves, authors must argue strongly why their findings are important and/or interesting (Swales \& Feak, 2009). In other words, the second research question refers to the way authors convince readers that their research topic and/or finding are important and therefore the article is important to read.

An independent rater involved in this study was a lecturer with a doctoral degree in Language Education at the Education Faculty of Bengkulu University. First, the independent rater was trained on how to identify the possible moves and argument styles in the texts with examples following a particular rhetorical analysis procedure as commonly found in text analysis studies. Then, he was given two weeks to do the processes of move identification and argument style analysis of all $20 \mathrm{RA}$ drafts from the corpus of this study. Inter-rater correlation agreement was then calculated and the results show an 80 percent agreement or an excellent inter-rater agreement (Orwin 1994, as cited in Kanoksilapatham, 2005). The difference only occurred in coding the possible communicative units found in the RA introductions and discussion while almost no difference occurred in coding the other sections of the RA drafts. However, after a few discussions between the researcher and the co-rater, a full agreement was finally achieved.

\section{Results}

Rhetorical pattern in each section of the RA drafts

The abstracts

The first rhetorical structure analysis on the RA drafts by Indonesian scholars in LLE in this study is on the abstracts. The analysis results are shown in Table 3.

\begin{tabular}{|c|c|c|c|}
\hline No & RA Abstracts & Frequency & Percentage \\
\hline 1. & 5 Moves & 10 & $50 \%$ \\
\hline 2 & 4 Moves & 4 & $20 \%$ \\
\hline 3. & 3 Moves & 5 & $25 \%$ \\
\hline 4. & 2 Moves & 1 & $5 \%$ \\
\hline 5. & 1 Move & 0 & $0 \%$ \\
\hline Total & & 20 & 100 \\
\hline
\end{tabular}

Table 3 indicates that the majority $(10$ or $50 \%)$ of the Indonesian authors participating in this study write their RAs with a complete 5 Moves as suggested by Peacock (2011), 4 or 20\% write 4 Moves, 5 or $25 \%$ write 3 Moves and 1 or $5 \%$ writes two Moves. An example of a fivemove abstract from the data of this study is given below.

Extract 1

(S-1)Audio recorded materials for language listening tests have been used extensively but to some extent, they are not authentic since in the reality people often not only listen to language but also watch how the language is used. (S-2)This study explored the possible ways of applying multimodality in teaching and testing listening comprehension for EFL students. (S-3)This study used the post-test only control group design to measure participants' performances concerning the two types of modality in the listening test. (S-4)The participants were 100 students of the English Department, Binus University 
Jakarta. (S-5)They were given two types of tests: Audio Listening Test (ALT) and Video Listening Test (VLT). (S-6) ALT was administered after the participants listened to a short video from YouTube, while VLT was administered after they listened and watched another short video from YouTube. (S7)Data were analyzed quantitatively to examine the differences in the effects of VLT or ALT on EFL students' performance in listening comprehension. (S-8) Results showed that students performed better in VLT to ALT. (S-9). This finding implies that multimodality can improve students' performance in listening comprehension. (S-10)Thus, the use of video materials should be encouraged in the teaching and learning of English as a foreign language (ACU-1).

Extract 1 is taken from an article titled 'Efficacy of Audio and Video Listening Tests for English as Foreign Language Students in Indonesia: Which is Better for Classroom Use? The authors start their abstract with a Move 1 (Introduction) in Sentence 1 (S-1) and followed by a Move 2 in Sentence 2 (S-2). In Sentences 3 to 7, they address the method of the study. The finding of the study is addressed in sentence 8 (S-8) while the conclusion is in Sentence 9 (S-9).

\section{The introduction section}

The second rhetorical structure analysis on the RA drafts by Indonesian scholars in LLE in this study is in the introduction sections. The analysis results are presented in Table 4.

Table 4. The Number of Moves in the Introduction Section of the RA Drafts

\begin{tabular}{rccc}
\hline No & RA Introduction & Frequency & Percentage \\
\hline 1 & 3 moves & 12 & $60 \%$ \\
\hline 2 & 2 moves & 7 & $35 \%$ \\
\hline 3 & 1 moves & 1 & $5 \%$ \\
\hline Total & & 20 & $100 \%$ \\
\hline
\end{tabular}

As can be seen in Table 4, the majority of the RA drafts (12 or 60\%) have 3 Moves in their introduction as suggested by Swales (1990 and 2004), 7 or $35 \%$ have two Moves and 1 or $5 \%$ has only one Move. Below is an example of the introduction section with 3 Moves.

Extract 2

$[P-1](S-1)$ In the last decade, there has been an increasing call for the integration of information and communication technology (ICT) into the teaching and learning process. ...

[P-2](S-7) ICT also plays important role in helping learners find reading sources from its original sources....

[P-3](S-11) Since the benefits that ICTs bring to English language learners are, for example, motivation enhancement (Schoepp \& Erogul, 2001), learners independence (Firth, 2005), and acquisition of skills (Galavis, 1998), they have been adopted by a large number of educational institutions in many countries in the world (Bubeng-Andoh, 2012)....

$[P-4](S-13)$ The use of ICT in the teaching and learning of English as a foreign language is one of the widely discussed issues in the field of education (Yunus and Saheli, 2012). (S-14) Several of ICT researchers have claimed that the use of ICT in education improves teachers' instructional process and facilitates students' learning process.... 
$[P-5](S-16)$ In spite of the fact that much attention has been paid to the investment of technology in classrooms by universities in Indonesia, adequate concern is not given to students' ICT use as well as their perception of using ICT to study English. ...

[P-6] (S-18) Zinan, W. and Sai, G.T.B. (2017) conducted a case study to investigate the EFL university students' perception in China about their ICT-based College English Course (CEC). (S-19) The result indicated that they were positive toward the application of ICT-based CEC. ...

$[P-7](S-22)$ This result was in agreement with the previous study by Tri, Dang Hoang and Nguyen, Nhung Hong (2014), who conducted an exploratory inquiry that examined the frequency, purposes, perception and expectation of using ICT both in non-learning and English learning purposes among Vietnamese EFL university students, also found that the majority of the students expressed positive attitudes toward ICT use in English learning. ... (UNP-3).

Extract 2 is taken from the article draft titled Making ICT use in English Language learning among undergraduate EFL learners: a challenge for English lecturers. From the above example, it can be seen that the author addresses a Move 1 (establishing a territory) in paragraphs 1 to 4 (P1 to P-4). Move 2 (establishing a niche) is written in paragraph 5 (P-5); then Move 3 (Occupying the niche) is written in paragraphs 6 to 7 (P-6 to P-7).

The method section

The third rhetorical structure analysis on the RA drafts by Indonesian scholars in LEE in this study is on the method sections. The analysis results are given in Table 5.

Table 5. The Number of Moves in RA Method Section of the RA Drafts

\begin{tabular}{cccc}
\hline No & Methods Section & Frequency & Percentage \\
\hline 1 & 3 moves & 13 & $65 \%$ \\
\hline 2 & 2 moves & 5 & $25 \%$ \\
\hline 3 & 1 move & 2 & $10 \%$ \\
\hline Total & & 20 & $100 \%$ \\
\hline
\end{tabular}

Table 5 indicates that the majority of the RA drafts (13 or $65 \%$ ) have 3 Moves in their method section; 5 RA drafts $(25 \%)$ have 2 Moves while $2(10 \%)$ of them have only 2 Moves. Below is an example of the Method section of an RA draft with 3 Moves.

Extract 3

[P-1] (S-1) The data were collected from early January till the end of February during the second semester of $2019 . .$.

[P-2] (S-6) The data for this research was the transcription of video lesson recordings, field notes, and stimulated recall interview audio recordings....

[P-3] (S-8) In analyzing the data, the researcher and an assistant who has expertise in the relevant languages: Bahasa Minang (BM) as the mother tongue, Bahasa Indonesia (BI) as the national language, and target language or English (TL) transcribed the video recordings and audio recordings following the transcription format adapted from Atkinson \& Heritage (1984). ... 
Extract 3 was taken from the method section of an article draft titled Teachers' Perception of Their Code-switching Practices in English as a Foreign Language Classes: The Results of Stimulated Recall Interview \& Conversation Analysis. Move 1 (describing data collection procedures) is written in paragraph 1 [P-1] of sentence (S-1 to S-5). Move 2 (describing procedures for measuring variables) is written in paragraph [P-2] of sentences (S-6 to S-7), while Move 3 (describing data analysis procedures) is addressed in paragraph $3[\mathrm{P}-3]$ at sentences $(\mathrm{S}-8$ to $\mathrm{S}-10)$.

The results and discussion section

The fourth rhetorical structure analysis in the RA drafts by Indonesian scholars in LEE in this study is on the results and discussion sections. The analysis results are presented in Table 6 below.

Table 6. The Number of Moves in RA Results and Discussion Section

\begin{tabular}{llcc}
\hline No & $\begin{array}{c}\text { Number of moves in the Result and } \\
\text { Discussion Section }\end{array}$ & $\begin{array}{c}\text { Number of RA } \\
\text { Drafts }\end{array}$ & Percentage \\
\hline 1 & 6 moves & 16 & $80 \%$ \\
\hline 2 & 5 moves & 1 & $5 \%$ \\
\hline 3 & 4 moves & 2 & $10 \%$ \\
\hline 4 & 3 moves & 1 & $5 \%$ \\
\hline 5 & 2 moves & 0 & $0 \%$ \\
\hline 6 & 1 move & 0 & $0 \%$ \\
\hline Total & & 20 & $100 \%$ \\
\hline
\end{tabular}

As shown in Table 6,16 or $80 \%$ of the RA drafts have a complete 6 Moves in their results and discussion section as suggested by Swales and Feak (2009); while 4 RA drafts (20\%) have 5 or fewer Moves. Below is an example of a discussion section with 6 Moves.

Extract 4

$[P-1]$ (S-1) To answer the research question as mentioned in the previous explanation, we divide it into four points. ...

[P-2] (S-6) There are five experts validated the model of an instrument for affective assessment based on a scientific approach.

Figure 1

[P-3] (S-9) Figure 1 presents the total score of validation for each validator was different....

[P-4] (S-16) The ideal concept is the assessment column and the detailed columns as a description of the affective assessment. ...

[P-5] (S-18) The results of the reliability, practicality, and effectiveness test show that the model of an instrument based on the scientific approach is reliable, practice, and effective to be used by English teachers to assess the effectiveness of students....

P-6] (S-20) Thus, the model of an instrument for affective assessment based on this scientific approach can already be used as a medium or an attempt by English teachers to assess the attitude of students during learning English.... 
[P-7] (S-27) This is also similar to the results of research ever conducted by Givens in 2010, where he examined the use of attitude assessment to know the students who like to read and not....

Extract 4 is taken from an article draft titled The development Model Instrument For Affective Assessment Based on Scientific Approach in English Language Teaching. It can be identified that Move 1 (background information) is addressed in paragraph 1 (P-1) sentences (S-1 to S-5) while Move 2 (statement of results) is in paragraph 2 (P-2) sentences (S-6) to (S-8). In these sentences, the authors present the research finding and relate them to the research question. Move 3 (statement of un/expected results) can be seen from paragraph 3 (P-3) and sentence 11 (S11) where the authors stated that the instrument is effective according to the expert. Move 4 (a reference to previous studies in the literature) is stated in paragraph 4 and sentence 17 (S-17), paragraph 5 [P-5] sentence 19 (S-19). In these sentences, the authors completed his/ her draft by reference to previous relevant studies. Move 5 (explanation of research results) from this RA draft is addressed in paragraph 6 [P-6] of sentences (S-20 to S-23). Move 6 (illustration to support the research results) is addressed in paragraph [P-7] as in sentence (S-28 to $\mathrm{S}-29)$.

The author's argument style in their RA abstracts, introduction, and discussion The argument style in the $R A$ abstract

The argument style analysis in the article abstracts is focused on Move 1 because this is where authors justify their research. From the analysis of RA abstracts, the majority of authors use appeal to 'problematicity' in supporting the importance of their research. Other argument types, such as appeal to salience, appeal to topicality, and appeal to magnitude are also used by several authors but much less frequently. Below is an example of an abstract in which the authors address the research problem in their Move 1.

Extract 5

$[P-1](S-1)$ Teachers often code-switch in the EFL classroom but the question of whether or not they are aware of their code-switching has not been satisfactorily answered (UNP-3).

Extract 5 is taken from a draft titled Teachers' perception of their code-switching practices in English as a foreign language class: the results of stimulated recall interview and conversation analysis. The authors claim that their article is important to read because there is a serious problem that must be solved. They write that teachers often code-switch in the EFL classroom but whether or not they realize it is still not known.

\section{The Author's Argument Style in Their RA Introduction}

The author's argument in the RA introduction is focused on Move 2 because this is where they give the rationale of their study. The majority of authors justify the importance of their study by claiming that there is a gap of knowledge in the literature from previous studies. Below is an example of a gap of knowledge statement taken from the draft or the article.

\section{Extract 6}

$[P-9](S-1) H o w e v e r$, not many studies have been conducted on writing the method section of research articles in English, in particular the study related to students' difficulties in writing the method section... (UNP-2). 
Extract 6 is taken from an article draft titled 'Perception of Undergraduate ELT Students on their difficulties in writing the method section of research articles in English'. In this article author presented arguments by showing a lack of information in the field of his or her research. The authors claim in sentence 1 (S-1) that not many studies have been conducted on writing the method section of RAs in English in a particular study is related to students' difficulties in writing the method section.

\section{The author's argument style in their $R A$ results and discussion}

The author's argument in the result and discussion section is focused on Moves 4 and 5; this is where they support the importance of their research findings. The analysis results show that the majority of authors state their interpretation and elaboration of their research findings and compare them with those of other authors. For this purpose, they use references to support their argument and convince readers that their findings are important and interesting. Below is an example of how authors justify the importance of their research results.

\section{Extract 7}

$[P-1](S-1)$ The finding related to attitudes and motivation is contradictory with the research results conducted by Munezane (2013), Fallah (2014), Öz et al. (2015) and Asmali (2016) that reveal attitudes and motivation influence the learners to communicate in the classroom... (Unib-3).

Extract 7 is taken from an RA draft titled Willingness to Communicate in a Foreign Language: Factors Affecting Enthusiasm of High-Ability-students in Higher Education to Communicate in a Classroom'. In this example, the authors argue that their research findings are important because they are contradictory to those of previous studies. Unlike the findings of previous studies on the same topic, they find that students are willing to communicate in the classrooms.

\section{Discussion}

The first question addressed in this study is how Indonesian scholars in LLE rhetorically organize their abstracts, introductions, method, results, and discussion sections in their English RA drafts. The results show that the majority of them have a complete five Moves of RA Abstract as the model suggested by Peacock (2011), a complete 3 Moves of RA Introduction as suggested by Swales (1990 and 2004), a complete 3 Moves of method section as suggested by Lim (2006), and a complete five or more Moves as suggested by Swales and Feak (2009). This implies that the majority of the RA drafts in the corpus of this study already follow the ideal rhetorical structure of a RA in terms of their obligatory communicative units. This also means that the lecturers as the participants in this study are already aware of how a good RA is in terms of its rhetorical structure. This is probably because the lecturers have attended workshops before writing the RA drafts and therefore, they can write a complete move of RA sections.

Arono \& Arsyad (2019) also found that lecturers who participated in several workshops on writing a journal article could satisfactorily improve the rhetorical quality of all sections of their RA drafts. According to Arono \& Arsyad, their article drafts become more argumentative and convincing with the use of more relevant references in all sections of the articles. This implies that the explicit instruction of academic writing through genre-based mentoring has been successful enough in educating university lecturers in social sciences and humanities in preparing their articles for international journal publication. Thus, it is believed that the lecturers' drafts are better 
in terms of their rhetorical structure and have a better chance to be accepted for publication in a reputable international journal.

The second research question in this study is how the authors craft an argument for the importance of their research topic/findings in their RA abstract, introduction and, discussion. The results show that the Indonesian authors in LLE tend to use problematicity appeal in their Move 1 (introduction) of their abstract to support the importance of their research topic. In other words, they justify the choice of the research topic because there is an important problem in the real-life world. According to Wang and Yang (2015), in this type of appeal, the authors claim centrality for their research topic by 'foregrounding the conflicts, problems, difficulties, or challenges a topic or a phenomenon involves' ( $\mathrm{p} .168$ ). This is probably because, for Indonesian authors, the problem is a very important aspect in their research and studies can be done only because there are practical problems in the real-life world (Arsyad, $2001 \&$ Adnan, 2009). However, this finding is different from that of Abdi and Sadeghi (2018) who found that the majority of authors (Iranian speakers writing in English and English native speakers in Applied Linguistics) used appeal to salience to justify their research topic. According to Wang \& Yang (2015), in appeal to salience, the authors support the importance or significance of a research topic because of the importance, usefulness, or advantages of a key construct involved in the topic in either the research world or the real world is directly stated. Wang and Yang (2015) also found that the use of 'problematicity' appeal in Applied Linguistic research articles have reduced significantly recently because access to references is more open today than in the past and therefore, authors tend to support the importance of their research topic based on the defects of previous studies rather than on the practical problems in the real world.

In the introduction section especially in Move 2, the majority of the Indonesian authors support their research by showing the gap of knowledge in the literature. According to Swales (1990 \& 2004), to show the research gap authors must evaluate the results of previous relevant studies or point at the gap of information in the relevant literature and for this purpose, authors need to review relevant literature in the introduction section of this study. Swales (2004) further suggests that this claim is important to win a competition to publish in a reputable international journal because, through this gap, authors promise to give valuable contributions or novelty of their research results to the available knowledge in the literature. This finding shows that Indonesian authors in the corpus of this study are already aware of the common argument style in the introduction section of an RA as published in international journals in English. This is probably because the Indonesian authors have been trained in a series of works on how to write RAs in English for international journals. This implies that workshops can be effective in improving their ability in writing RAs in English at least from the rhetorical structure and argument style aspects as far as the workshops use an appropriate method such as genre-based methods (Arono \& Arsyad, 2019).

In the discussion section, the majority of the Indonesian authors interpret and elaborate their findings and compare them with those of other authors. This implies that the Indonesian authors in the corpus of this study already comply with the argument style of RA discussion published in international journals. According to Hagin (2009) and Hess (2004), authors are expected to interpret and elaborate their findings in their RA discussion and this can be done by responding and commenting on every issue in the research questions (Branson, 2004 and Thyer, 2008). However, this is still an incomplete argument in the discussion section of an article because, according to Dudley-Evan (1994) and Swales (2004), authors should also explain and illustrate their findings in their RA discussion. In other words, the authors need not only to interpret and 
elaborate on their findings but also explain and illustrate them to convince readers that their findings are acceptable, important, and interesting.

This finding is different from that of Arsyad et al. (2020) when they analyzed the argument style of RA discussions written in Indonesian by Indonesian writers in language-related fields and published in Indonesian journals. They found that the majority of the Indonesian authors interpret and elaborate their findings; however, only a few of them relate their findings with those of other authors in the previous relevant studies. According to Arsyad et al., this is probably because the Indonesian authors may have used the Indonesian style when writing RA discussion in Indonesian and for Indonesian readers. Another possible reason is that there are a variety of conventions in writing the discussion section of RAs between different disciplines (Sabet \& Kazempouri, 2015). Holmes (1997), for example, found that the discussion section of RAs in History rarely has reference to the previous research findings. According to Holmes, this is because authors in the field of History do not have an agreement in writing research articles for journals yet.

\section{Conclusion}

From the results and discussion of this study, it can be concluded that the majority of the Indonesian authors in LLE in the corpus of this study have written complete moves in their RA abstracts, introduction, methods, and results and discussion in their RA drafts in English. This may be because they have attended a series of workshops on writing RAs in English for international journals using a genre-based method. However, from the argument style, their RA drafts can be considered incomplete because they still rely heavily on the 'problematicity' appeal in their RA abstracts rather than on more popular types of appeal, such as appeal to salience and appeal to magnitude. Besides, the Indonesian authors also tend to only interpret and elaborate their findings in their RA discussion, and very few of them explain and illustrate them although the majority of them compare their findings with those of other authors in relevant previous studies. Therefore, it is suggested that Indonesian authors follow the argument styles of each section as commonly found in articles already published in reputable journals in the same field.

This study focused only on authors in LLE; therefore, we could not generalize these findings to authors in other disciplines. It is suggested that other studies be conducted on RA drafts written by authors in other disciplines such as social and political sciences, geography, and arts. Thus, findings from studies in different fields can complement each other and provide a more comprehensive understanding of the rhetorical and argument style in RA drafts written by faculty members in Indonesia. Also, this study investigated only the surface features of the RA drafts; it did not discuss the content quality of the RAs. Future studies can focus on the content quality of the RA drafts such as, on the relevance and newness of the references cited in the articles and the strength of the argument crafted in the articles in the eyes of field specialists. In addition, this study only included 20 RA drafts which can be considered small in number and therefore, a further study could involve more authors to write more RA drafts to analyze.

The results of this study have an implication for the teaching of article journal writing especially for young faculty members. Indonesian authors need to strengthen their argument in their articles, especially in the abstract, introduction and discussion. This can be done by using various types of centrality claims and various research gap strategies. In the discussion section, they need to strengthen their argument on the research finding by interpreting and illustrating their findings. This is to convince readers including journal editors and reviewers that they are willing to accept a manuscript to be published in a reputable journal. 
Declaration of conflicting interest

We declare that there is no conflict of interest regarding the publication of this article.

Funding acknowledgement

This research was financially funded by the Postgraduate Program of English Education of Education Faculty of University of Bengkulu in 2020.

\section{References}

Abdi, J. \& Sadeghi, K. (2017). Promotion through claiming centrality in L1 and L2 English Research Article Introductions. International Journal of English Studies, 18(1), 53-70. doi: $10.6018 / \mathrm{ijes} / 2018 / 1 / 297381$

Adnan, Z. (2014). Prospects of Indonesian Research Articles (RAs) Being Considered for Publication in Center Journals: A Comparative Study of Rhetorical Patterns of RAs in Selected Humanities and Hard Science Disciplines, in Lyda, Andrzej and Krystyna Warchal (Eds) Occupying Niches: Interculturality, Cross-culturality and Aculturality in Academic Research, Cham Heildeberg: Springer, 66-79.

Adnan, Z. (2009). Some potential problems for research articles written by Indonesian academics when submitted to international English language journals. The Asian EFL Journal Quarterly, 11, 107-125. https://rune.une.edu.au/web/handle/1959.11/5741

Arsyad, S. (2014). The Discourse Structure and Linguistic Features of Research Article Abstracts in English by Indonesian Academics. Asian ESP Journal, 10(2), 191-224. https://www.asian-esp-journal.com/december-2014/

Arsyad, S. (2013a). A Genre-based Analysis of Indonesian Research Articles in the Social Sciences and Humanities Written by Indonesian Speakers. Journal of Multicultural Discourses, 8(3), 234-254. https://doi.org/10.1080/ 17447143.2013.849711

Arsyad, S. (2013b). A Genre-Based Analysis on Discussion Section of Research Articles in Indonesian Written by Indonesian Speakers. International Journal of Linguistics, 5(4), 5070. DOI. https://doi.org/10.5296/ijl.v5i4.3773

Arsyad, S., Arono, Ramadhan, S., \& Iramaisarah (2020). The rhetorical problems experienced by Indonesian lecturers in social sciences and humanities in writing research articles for international journals. Asian Journal of Applied Linguistics, 7(1), 116-129. http://caes.hku.hk/aja

Arsyad, S. \& Arono (2016). Potential problematic rhetorical style transfer from the first language to foreign language: a case of Indonesian authors writing research article introductions in English. Journal of Multicultural Discourses, 11(3), 315-330. https://doi.org/10.1080/17447143.2016.1153642

Arsyad, S. \& Adila, D. (2018). Using local Style When Writing in English: The Citing Behaviour of Indonesian Authors in English Research Article Introductions. Asian Englishes, 20(2), 170-185. https://doi.org/10.1080/13488678.2017.1327835

Arsyad, S., \& Wardhana, D. E. C. (2014). Introduction in Indonesian social sciences and humanities research articles: How Indonesian Justify their research project. Linguistik Indonesia, 32(2), 149-163. http://linguistik-indonesia.org/images/files/3.pdf

Arsyad, S., Zaim, M. \& Susyla, D. (2018). Review and Citation Style in Research Article Introduction: A Comparative Study between National and International English-Medium Journals in Medical Sciences. Discourse and Interaction, 11(1), 28-51. https://doi.org/10.5817/DI2018-1-28 
Arono \& Arsyad, S. (2019). The Effect of Genre-Based Mentoring on Rhetorical Quality of Research Article Drafts by Indonesian Lecturers in Social Sciences and Humanities. International Journal of Instruction, 12(3), 35-50. http://www.eiji.net/dosyalar/iji_2019_3_3.pdf

Baber, W.W. (2018). Crafting arguments in academic writing. Academe, 1(1) 30-40. https://www.researchgate.net/publication/326741418

Branson, R.D. (2004). Anatomy of a research paper. Respiratory Care, 49(10), 1222-1228. Retrieved from http://rc.rcjournal.com/content/respcare/49/10/1222.full.pdf

Creswell, J.W. (2009). Research Design: Qualitative, Quantitative and Mix Method Approaches, Los Angeles, CA: Sage.

Coulthard, M. (1994). Advances in Written Text Analysis, New York, NY: Routledge

Dudley-Evans, T. (1994). Genre Analysis: an Approach to Text Analysis for ESP. In Malcolm Coulthard (Ed.), Advances in Written Text Analysis, London: Routledge, 219-228.

Hagin, S. (2009). How to write the results and discussion sections. English 1102/66 of Kennesaw State University, Spring.

Hess, D. R. (2004). How to write an effective discussion. Respiratory Care, 49(10), 1238-1241. Retrieved from http://rc.rcjournal.com/content/respcare/49/10/1238.full.pdf

Holmes, R. (1997). Genre analysis, and the social sciences: An investigation of the structure of research article discussion sections in three disciplines. English for Specific Purposes, 16(4), 321-337. https://doi.org/10.1016/S0889-4906(96)00038-5

Kanoksilapatham, B. (2005). Rhetorical structure of biochemistry research articles. English for Specific Purposes 24, 269-292. https://doi.org/ 10.1016/j.esp.2004.08.003

Kemristekdikti (2016). Kekuatan 50 Institusi Ilmiah Indonesia: Profil Publikasi Ilmiah Terindeks Scopus (The strengths of 50 Indonesian scientific institutions: Scopus indexed scientific publication profiles), Jakarta: Direktorat Pengelolaan Kekayaan Intelektual, Direktorat Jenderal Penguatan Riset dan Pengembangan Kemenrist ekdikti Indonesia.

Lim, J. M. H. (2006). Method sections of management research articles: A pedagogically motivated qualitative study. English for Specific Purposes, 25(3), 282-309. doi:10.1016/j.esp.2005.07.001.

Mirahayuni, N. K. (2002). Investigating Textual Structure in Native and Non-native English Research Articles: Strategy Differences Between English and Indonesian Writers, Unpublished Ph.D. Dissertation, the University of New South Wales, Sydney, Australia.

Peacock, M. (2011). The Structure of the Method section in Research Articles Across Eight Disciplines. The Asian ESP Journal, 7(2), 99-123. https://scholars.cityu.edu.hk/en/publications/publication （5a833362-bb37-4f08-8927536da662a0bb).html

Rifai, M. A. (1995). Pegangan Gaya Penulisan, Penyuntingan dan Penerbitan Karya Ilmiah Indonesia (Writing Manual for Indonesian Acdemic Texts). Yogyakarta: Gadjah Mada University Press.

Sabet, M. K., \& Kazempouri, M. (2015). Generic structure of discussion sections in ESP research articles across international and Iranian journals. Advances in Language and Literary Studies, 6(2), 87-95. Doi:10.7575/aiac.alls.v.6n.2p.87

Safnil (2003). The rhetorical style of Indonesian research article introductions: A genre-based analysis. The Asia-Pacific Education Researcher, 12(1), 27-62. Retrieved from https://www.academia.edu/7294045/The_Rhetorical_Style_of_Indonesian_Research_Artic le_Introductions_A_Genre_Analysis_Study 
Safnil (2001). Rhetorical Structure Analyses of the Indonesian Research Articles. An unpublished $\mathrm{Ph} . \mathrm{D}$. thesis in the Australian National University, Canberra Australia

Swales, J. M. (2004). Research Genre: Explorations and Applications, Cambridge: Cambridge, England: Cambridge University Press.

Swales, J. M. (1990). Genre Analyses: English in Academic and Research Settings, Cambridge, England: Cambridge University Press.

Swales, J. M. \& Feak, C. B. (2009). Abstracts and the Writing of Abstracts. Michigan, MI: University of Michigan.

Thyer, B. A. (2008). Preparing research articles. Oxford, England: Oxford University Press.

Wang, W., \& Yang, C. (2015). Claiming centrality as a promotion in applied linguistics research article introductions. Journal of English for Academic Purposes, 20, 162-175. https://doi.org/10.1016/j.jeap.2015.05.002. 